\title{
噴霧乾燥法による微小粒子コーティングの試み
}

\author{
山田 則 行*, 安 部 英 - *, 広末 英 晴*
}

\section{Coating of Fine Particles by Spray Drying of Suspensions}

by

\author{
Noriyuki YAMADA ${ }^{\dagger}$, Eiichi $\mathrm{ABE}^{\dagger}$ and Hideharu HIROSUE ${ }^{\dagger}$
}

Key Words : Spray Drying, Atomization, Coating

\section{1. 緒 言}

従来の機械的方法, たとえば, 流動層コーティング 法 $^{1.2)}$ では被コーティング粒子の粒度の下限が50 $\mu \mathrm{m}$ 程 度とされている。一方, 比較的大きな粒子を含む䋰濁 液の微粒化においては, 粒子が液滴から飛び出す場合 があることが知られている3 ば懸濁液の調製, 微粒化の方法を適切に設定すること で，機械的方法の 1 つである噴霧乾燥法により, $50 \mu \mathrm{m}$ 程度以下の粒子をコ一ティグできる可能性がある。本 実験では, 噴霧液滴からの橧濁粒子の飛び出し現象を 利用して，1個の粒子の周囲を高分子膜で被覆するこ とを試みる。そして, 凝集することなく被覆された粒 子(後述の単核マイクロカプセル)の, 収率に及ぼす操 作条件の影響を検討する。

\section{2. 実験方法}

実験に用いた粒子は既報5)の方法により調製した噴 霧乾燥粒子である。すなわち, 中位径がそれぞれ約 $3 \mu \mathrm{m}$ 炭化けい素及び約 $2 \mu \mathrm{m}$ の塩基性炭酸マグネシウ ムを核物質とし, コロイダルシリカを殼物質とする球 形の無機質殼粒子である。以下ではこの粒子を核粒子 と呼ぶ。この粒子の組成をTable 1に示す。

噴霧乾燥に供する㲘濁液は所定の粒度, すなわち,

1994年 11月 10 日受付

粉体工学会第30回夏期シンポジウム(1994年7月，函南)にて発表

* 九州工業技術研究所 ( 7841 佐賀県島栖市宿町)

TEL. 0942-82-5161

$\dagger$ Kyushu Natinal Ind. Res. Instiute.,

(Shuku, Tosu-Shi Saga 841)

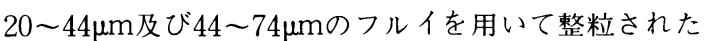
核粒子を，エチルセルロース(以下，ECと略称する） を溶解させたイソプロパノ一ル溶液(以下, EC溶液と 略称する)に分散させたものである。㦟濁液の調製範 囲をTable 2(a)に示す。すなわち, EC量とイソプロ パノール量の比率, 核粒子量とイソプロパノール量の

Table 1 Compositions of core particles

\begin{tabular}{|c|c|c|c|c|}
\hline $\begin{array}{l}\text { Core material } \\
\text { Shell material } \\
\text { Vol. fraction }\end{array}$ & $\mathrm{SiC}^{* 1}$ & $\mathrm{MHC}^{* 2}$ & $\begin{array}{c}\mathrm{Si} 500^{* 3} \\
0.33\end{array}$ & $\begin{array}{c}\mathrm{Si}^{8} \mathrm{P}^{* 4} \\
0.35\end{array}$ \\
\hline \multicolumn{5}{|c|}{ Apparent particle density ${ }^{* 5} \quad 1610 \mathrm{~kg} / \mathrm{m}^{3}$} \\
\hline \multicolumn{5}{|c|}{$\begin{array}{l}* 1: \text { Green silicon carbide } \# 4000(3 \mu \mathrm{m}) \\
* 2: \text { Magnesium hydroxide carbonate }(2 \mu \mathrm{m}) \\
* 3: \text { Si500: }<5 \mathrm{~nm} \\
* 4: \text { Si80P }: 80 \mathrm{~nm} \\
\text { *5: measured by mercury porosimetry at atmospheric } \\
\quad \text { pressure }\end{array}$} \\
\hline
\end{tabular}

Table 2 Experimental coditions (a) Ratio of components in suspensions

Ratio of EC* to 2-propanol $\quad 0.03 \sim 0.145 \mathrm{~kg} / \mathrm{kg}$
Ratio of core particles to 2-propanol $\quad 0.20 \sim 0.960 \mathrm{~kg} / \mathrm{kg}$ Ratio of EC to core particles $0.07 \sim 0.200 \mathrm{~kg} / \mathrm{kg}$

*EC : ethyl cellulose

(b) Specification of two fluid nozzles

\begin{tabular}{llr}
\hline Air nozzle & : inside diameter & $1.24 \mathrm{~mm}$ \\
& outside diameter & $1.70 \mathrm{~mm}$ \\
& area & $1.06 \mathrm{~mm}^{2}$ \\
Liquid nozzle & : inside diameter & $0.90 \mathrm{~mm}$ \\
& area & $0.64 \mathrm{~mm}^{2}$ \\
Air pressure & $:$ & 98 or $196 \mathrm{kPa}$ \\
\hline
\end{tabular}


比率を変化させた。それに伴い, EC量と核粒子量の 比率も変化した。噴霧化装置として二流体ノズルを採 用した。ノズルの仕様をTable 2(b)に示す。噴霧乾 燥には既報 ${ }^{5)}$ に示した塔径 $1.6 \mathrm{~m}$, 塔高 $2.2 \mathrm{~m}$ の噴霧乾燥 塔を用いた。乾燥塔への加熱空気の入口温度は $80^{\circ} \mathrm{C}$,

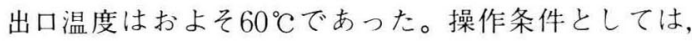
二流体ノズルの空気圧を変化させた。愳濁液の供給速 度は $4.5 \mathrm{~kg} / \mathrm{h}$ で一定としたが, 懸濁液の組成を変える ことによって粘度はかなり変化した。

\section{3. 実験結果および考察}

\section{1 噴霧乾燥粒子の性状}

噴霧乾燥粒子のSEM写真をFig. 1(a), (b)に示 す。(a) は噴霧乾燥粒子中に核粒子を 1 個含む場合で, 以下ではこれを単核マイクロカプセル(単核 $M C$ ) と呼 び，(b)のように噴霧乾燥粒子中に核粒子を複数個含 む場合を複核マイクロカプセル(複核 $\mathrm{MC}$ ) と呼ぶ。

単核 MCは核粒子の周囲を薄いEC膜で被覆したも のであるから，核粒子の粒度と単核MCの粒度とはほ ぼ同じものと見なすことができよう。そこで，噴霧乾 燥粒子中の単核MCは, 核粒子を整粒したふるいによ るふるい分けによって回収した。SEMによる観察か ら、このようにして回収された粒子はほとんどが単核 MCであることを確認したが，一部に後述のECのみの 粒子や，複核のMCの混入も確認された。ただし，こ れらの量は極めて少ないものであったので，子るい分 けによって回収した粒子を単核MCと見なした。単核 $\mathrm{MC}$ の収率は回収した全噴霧乾燥粒子中の単核MCの 質量分率として求めた。

\section{2 噴霧乾燥粒子へのECの付着量}

噴霧乾燥粒子へのECの付着量は, 噴霧乾燥粒子の 所定量をジクロロメタンにより洗浄し, 洗浄前後の質 量差を $\mathrm{EC}$ 量と見なして求めた。なお，核粒子はジク

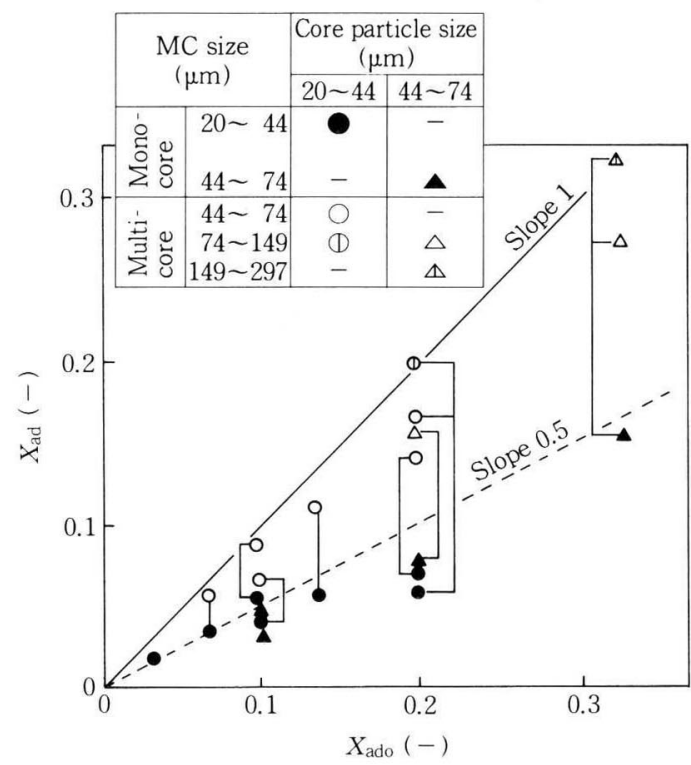

Fig. 2 Relationship between $X_{\text {ad }}$ and $X_{\text {ado }}$

ロロメタンには溶解しないことを確認している。

Fig. 2は単核MCとなっている噴霧乾燥粒子をジク ロロメタンにより洗浄し, 次式で定義したECの付着 量 $X_{\text {ad }}$ 示したものである。

$$
X_{\mathrm{ad}}=\frac{\mathrm{EC} の \text { 質量 }}{\text { 核粒子の質量 }}
$$

$X_{\text {ado }}$ は懸濁液の調製時のそれであり, 理論付着量であ る。図中には複核MCについてのECの付着量も示し た。線で結ばれた測定点は同一実験で得た噴霧乾燥粒 子を単核及び複核 $\mathrm{MC}$ へるい分けたものの $X_{\mathrm{ad}}$ と $X_{\text {ado }}$ の関係を示している。同四より，単核MCの場合 に付着量 $X_{\mathrm{ad}}$ が $X_{\mathrm{ado}}$ の増加とともに大きくなること, また，付着率 $X_{\mathrm{ad}} / X_{\text {ado }}$ は理論值の $50 \%$ 以下であること がわかる。一方，複核MCの場合には付着率は単核

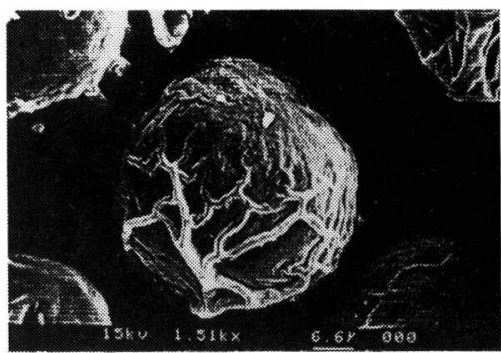

(a)

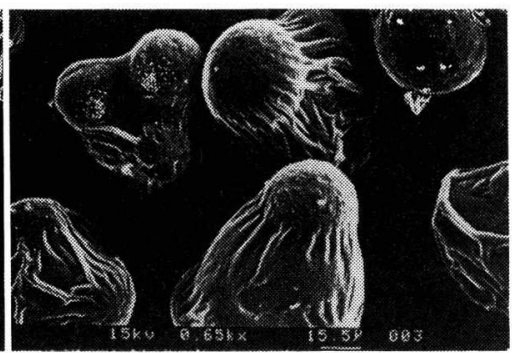

(b)

Fig. 1 SEM photographs of spray-dried particles

(a) Under size products : Monocore microcapsules

(b) Over size products: Multicore microcapsulles 


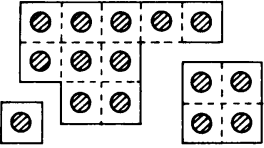

(a) EC particle (2) +0

Monocore MC

Fig. 3 Split model of suspension into monocore or multicore microcapsulles by atomization

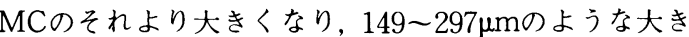
な複核MCではほぼ100\%の付着率となる場合がある ことがわかる。

Fig. 3は眯濁液及び噴霧化過程をモデル的に 2 次元 表示したものである。すなわち，㦟濁液を格子で分割 し，1つの格子に核粒子が 1 個含まれるとし，そして このような㦟濁液が単核及び複核MCへ分裂する過程 を示している。噴霧化においては，(a)のようにある 程度のEC溶液を付随した粒子とEC溶液のみの滴とに 分裂すると推測される。前者は単核MCとなり, 後者 はECのみの粒子となる。現実には㦟濁粒子の大きさ のレベルにおいては粒子が䊝濁液中では必ずしも均一 に分散していないために，粒子を含まない格子が存在 しECのみの粒子を生成することも考えられる。これ らの現象のために, Fig. 2において示したように単核 $\mathrm{MC}$ 中のECの付着率が50\%以下になったと考えられ る。一方，(b)のように複数個の核粒子を含む場合に は, Fig. 2の結果からみて, 分裂時にECのみを含む滴 への分離は少なく, ECの付着率がほぼ100\%に近い複 核MCが得られたと思われる。

\section{3 単核 $\mathrm{MC}$ の収率と操作条件との関係}

噴霧乾燥法による単核MCの調製においては，榡濁 液を噴霧する際における液滴からの粒子の飛び出し現 象を利用していることから，この現象に関する操作条 件としては懸濁液の性質(懸濁粒子の粒径, 固体濃度 とEC濃度を反映する慜濁液の粘度など)，ノズルの空 気圧力が考えられる。Fig. 4は，核粒子を㦟濁させた ときの㦟濁液の粘度と単核MCの収率との関係を示し たものである。収率は同一の空気圧力において, 慜濁 液の粘度が低くなるほど，また，空気圧力が高いほど 高くなることがわかる。

二流体ノズルによる㲘濁液の噴蓩における液滴の中 位径は，Kim-Marshall式により推算することができ

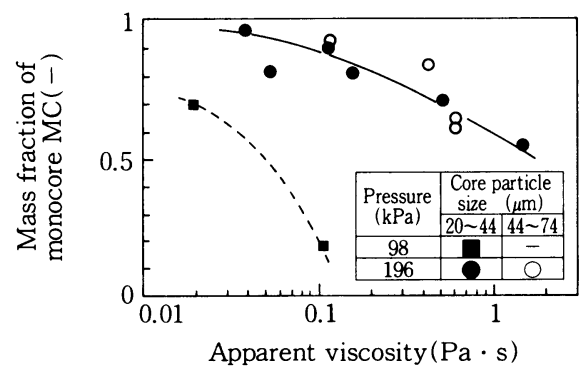

Fig. 4 Influence of atomizing pressure and apparent viscosity of suspensions on mass fraction of monocore microcapsules

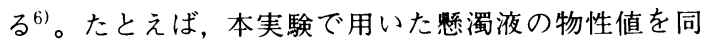
式に代入して中位径を計算すると, 空気圧力が $98 \mathrm{kPa}$ において, 粘度が $1 \mathrm{~Pa} \cdot \mathrm{s}$ のき $388 \mu \mathrm{m}, 0.1 \mathrm{~Pa} \cdot \mathrm{s}$ のき $179 \mu \mathrm{m}$ であり, 空気圧力が198kPaにおいて, 粘度が $1 \mathrm{~Pa} \cdot \mathrm{s}$ のき $162 \mu \mathrm{m}, 0.1 \mathrm{~Pa} \cdot \mathrm{s}$ のき $75 \mu \mathrm{m}$ である。こ のことから，単核MCの収率を高くする操作条件は中 位径を小さくすることに対応していることがわかる。，

噴蓩乾燥操作は, 本来, 微粒子の造粒に適用されて いる。したがって，核粒子の粒径が小さくなるにつれ て単核MCの収率が減少することが予想される。しか し，核粒子径の影響を空気圧力 $196 \mathrm{kPa}$ で操作した場 合について見ると，本実験範囲，すなわち20〜 $44 \mu \mathrm{m}$

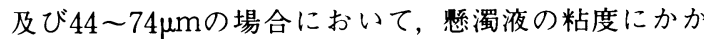
わらず収率には明確な差が認められなかった。単核 MCの収率に及ぼす核粒子径の効果については，核粒 子径の範囲を広げる等のより詳細な検討が必要であ る。

\section{4. 結言}

比較的大きな粒子をエチル七ルロースを溶解したイ ソプロパノール溶液に㦟濁させて噴霧乾燥すると, 操 作条件に依存して，1個の粒子の周囲をエチルセルロ 一スで被覆した単核のマイクロカプセルと，複数個を 被覆した複核のマイクロカプセルが生成することが分 かった。全回収粒子に対する単核マイクロカプセルの 収率は，瑟濁液の粘度が低いほど，また噴霧化のため の空気圧力が高いほど高くなり，これは噴霧時に生成 する液滴の中位径を小さくする条件に対応しているこ とが分かった。

\section{Nomenclature}

$X_{\mathrm{ad}}$ : ratio of adhered ethyl cellulose to core particle
$X_{\text {ado }}$ : initial ratio of adhered ethyl cellulose to core particles in suspension

$(\mathrm{kg} / \mathrm{kg})$ 


\section{References}

1) Abe, E., N. Yamada and H. Hirosue : J. Soc. Powder Technol., Japan, 28, 689(1991)

2) Maki, T., N. Umeki, Y. Ozawa : J. Soc. Powder Technol., Japan, 25, 338(1988)

3) Yamada, N., H. Hirosue, H. Ihara and T.

Murayama : J. Soc. Powder Technol., Japan, 20, 211 (1983)
4) Sato, K., K. Okiura, A. Baba, K. Shoji and I. Akiyama : Tran. Japan Soc. Mech. Eng., (B), 53, 2995(1987)

5) Yamada, N., E. Abe and H. Hirosue : Kagaku Kogaku Ronbunshu, 18, 781(1992)

6) Kim, K. Y. and W. R. Marshall : AIChE Journal, 17, 575(1971) 